DOI: https://doi.org/10.34069/AI/2021.45.09.29

How to Cite:

Popov, R.A., Sekisov, A.N., Solovyova, E.V., Shipilova, N.A., \& Savenko, A.A. (2021). Resource-saving factor in the development of Russian cities. Amazonia Investiga, 10(45), 293-301. https://doi.org/10.34069/AI/2021.45.09.29

\title{
Resource-saving factor in the development of Russian cities
}

\section{РЕСУРСОСБЕРЕГАЮЩИЙ ФАКТОР В РАЗВИТИИ РОССИЙСКИХ ГОРОДОВ}

\author{
Received: July 12, 2021
}

Accepted: September 8, 2021

\author{
Written by: \\ Rinad A. Popov ${ }^{114}$ \\ https://orcid.org/0000-0002-1982-120X \\ Aleksandr N. Sekisov ${ }^{115}$ \\ https://orcid.org/0000-0002-4810-3741 \\ Ekaterina V. Solovyova ${ }^{116}$ \\ https://orcid.org/0000-0002-8354-5887 \\ Nataliya A. Shipilova ${ }^{117}$ \\ https://orcid.org/0000-0002-9531-2394 \\ Andrey A. Savenko ${ }^{118}$ \\ https://orcid.org/0000-0001-5268-2021
}

\begin{abstract}
The purpose of the article is to identify the problems of Russian cities and urban-type settlements from the standpoint of their historical and economic development. Using the methodology of economic, statistical and retrospective analysis, it was revealed that along with the growth of large cities in recent years, there has been a tendency towards a reduction in small settlements, which is associated with a decrease in industrial production. The result of this is the active development of urban processes, leading to the concentration in large cities of the scientific, technical and intellectual and production potential of the regions, their transformation into self-sufficient centers for the development of territorial socio-economic locations. The result of the study is the substantiation of the need to create new methodological approaches to the development and placement of productive forces, planning of urban areas, solving problems of energy and resource supply of territories on the basis of achieving their ecological and economic efficiency. The concept of the decisive role of the resource-saving factor in the process of
\end{abstract}

\section{Аннотация}

Целью статьи является выявление проблем российских городов и поселков городского типа с позиций их исторического и экономического развития. Посредством методологии экономико-статистического и ретроспективного анализа выявлено, что наряду с ростом крупных городов в последние годы наблюдается тенденция к сокращению малых поселений, что связано со снижением промышленного производства. Результатом этого становится активное развитие урбанистических процессов, приводящее к концентрации в крупных городах научно-технического и интеллектуально-производственного потенциала регионов, превращению их в самодостаточные центры развития территориальных социально-экономических локаций. Результатом проведённого исследования является обоснование необходимости создания новых методологических подходов к развитию и размещению производительных сил, планировке территорий городов, решению задач энерго- и ресурсообеспеченности

\footnotetext{
$114 \mathrm{PhD}$, Doctor of Economics, Professor, Department of Technology, Organization, Construction Economics and Real Estate Management, Institute of Construction and Transport Infrastructure, Kuban State Technological University, Russia.

${ }^{115} \mathrm{PhD}$, Candidate of Economic Sciences, Associate Professor, Department of Technology, Organization, Construction Economics and Real Estate Management, Institute of Construction and Transport Infrastructure, Kuban State Technological University, Russia. ${ }^{116} \mathrm{PhD}$, Doctor of Economics, Professor, Department of Technology, Organization, Construction Economics and Real Estate Management, Institute of Construction and Transport Infrastructure, Kuban State Technological University, Russia.

${ }^{117} \mathrm{PhD}$ (Candidate of Economic Sciences), Associate Professor, Department of Technology, Organization, Construction Economics and Real Estate Management, Institute of Construction and Transport Infrastructure, Kuban State Technological University, Russia. ${ }^{118} \mathrm{PhD}$, Candidate of Economic Sciences, Associate Professor, Department of Technology, Organization, Construction Economics and Real Estate Management, Institute of Construction and Transport Infrastructure, Kuban State Technological University, Russia.
} 
urbanization of territories is substantiated. It was revealed that the approach to the analysis and modeling of the city economy when considering it as a "quasi-corporation" involves the formation of an integrated reproduction system based on increasing the efficiency of the use of territory resources, which translates the process of planning the development of the urban environment into the category of business process technologies.

Keywords: urbanization, city, urban planning, productive forces, resources, efficiency.

\section{Introduction}

The purpose of the article is to identify the problems of Russian cities and urban-type settlements from the standpoint of their historical and economic development. The resource-saving factor in the development of Russian settlements from a historical perspective is manifested in their emergence and formation near consumed natural resources such as water, material, energy. In the past, and often even today, during the development of mineral deposits near industrial facilities, settlements for workers were created both on the basis of previously existing settlements and new ones. The owners of new mines, coal mines, factories and factories at minimal cost built temporary residential buildings in the form of dormitories, in which they settled the families of workers, and in this inexpensive way "tied" people to jobs. This method of saving resources was the most popular in Soviet Russia during the first five-year plans and the post-war decade, when the destruction of the Second World War was being overcome. Starting in the 60s of the last century, intensive housing construction began in the country, which gradually (in about 20 years) resettled the heirs of the first barracks settlers into separate, relatively small, but comfortable apartments. This was facilitated by the emergence of a large number of house-building plants, at least one house-building plant in each regional center, which produced 100 thousand square meters of apartments per year. Another factor in the development of construction was technical progress, the creation of new materials, construction machines, an increase in the energy supply of construction projects, the improvement of the qualifications of workers of mass территорий на основе достижения их эколого-экономической эффективности. Обосновывается концепт об определяющей роли фактора ресурсосбережения в процессе урбанизации территорий. Выявлено, что подход к анализу и моделированию хозяйства города при рассмотрении его как «квазикорпорации» формирование комплексной системы воспроизведения, основанной на повышении эффективности применения ресурсов территории, что переводит процесс планирования развития городской среды в разряд бизнес-процессных технологий.

Ключевые слова: урбанизация, город, градостроительство, производительные силы, ресурсы, эффективность.

professions and the engineering staff. Currently, any able-bodied Russian has the opportunity to get a mortgage loan from a bank for up to 20 years and immediately buy an apartment or participate in the construction of an apartment building.

In the 30-60s in our country, the development of productive forces was carried out from the standpoint of resource conservation along the line of the formation of mono-industrial cities and urban-type settlements according to the principle: one city or village is adjacent to one large plant. In this way, many new cities and urban-type settlements appeared on the map of the country; among them are Norilsk, Bratsk, Angarsk, Volzhsky, Togliatti, Urengoy, etc. At the same time, new industrial enterprises were created in the peripheral part of historically formed large cities, which used the labor resources of these cities, and also financed housing construction for the emergence of additional personnel. The result of this process was the formation of special territorial-industrial zones in large cities and at some distance from new residential neighborhoods. Such microdistricts in some cities were called "sotsgorod" (social city), "Cheryomushki" in others, by analogy with Moscow Cheryomushki (microdistrict, frontally built up in the 60s with new multi-storey residential buildings). Subsequently, such residential neighborhoods with a population of 20-40 thousand inhabitants were called "dormitory areas", since they provided services for housing and communal services, consumer services, health care and secondary education, but there were practically 


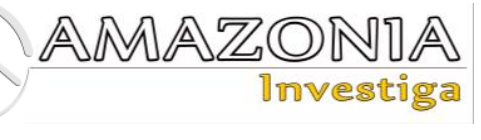

no places for employment.

In such a scheme of urban planning, the problem of maximum use of resources was effectively solved, on the one hand, the life support of the population, on the other hand, the extraction of a synergistic effect from the concentrated location of both residential areas and industrial enterprises. At the same time, the main organizational and technical difficulty was the transportation of passengers between the industrial and residential areas in the morning and evening hours. Moreover, it was necessary to deliver the children of workers to kindergartens, since at that time there were not enough children's places in the microdistricts. This problem was solved by organizing the running of special buses for preschool children. In terms of the resources of that time, such a solution can be considered quite effective.

Under the influence of the imperatives of resource conservation in the 1960s and 1980s, satellite cities began to appear in the vicinity of the largest Russian cities near production facilities, in which the issues of employment and social development were comprehensively resolved. If earlier cities developed practically according to the same scenario - from the center to the outskirts (from the town hall and the shopping area to the fortress walls and outside the walls near them), then later such factors of urban planning began to lose their relevance. The determining factors in the growth of Russian cities in recent years have been their high resource availability and economic synergetics obtained on the basis of diversified interactions. Simultaneously with the expansion of large cities in recent years, there has been a process of reduction of small settlements due to the extinction of industrial enterprises, reduction of places of employment. The result of such a contradictory process is a modern map of the settlement of settlements, in which the urbanistic (from the Latin urba - city) emphasis of development is quite clearly visible - the pulling of the intellectual and production potential of territories into large cities, turning them into selfsufficient nuclei of regional socio-economic locations, "centers development". At the same time, the prospect of the functioning and development of small settlements remains problematic.

\section{Literature Review}

The problem of the spatial organization of the economy in a relatively holistic form dates back to the second half of the 19th century in the works of representatives of the German school A. Weber. A. Weber was the first to formulate the idea of the formation of settlements in conjunction with the development of industrial enterprises with positions of the resource approach (Weber, 1926). A. Weber considered the minimum production costs to be the main "factor of placement". Along with the resource factor, he proposed to take into account the sales factor in the "placement" problem, which in some cases may turn out to be more significant than the resource factor in terms of the total costs of production and sales of products. In 1934, from the standpoint of a functional approach to the development of territories, three sectors of the city's economy were identified: the primary sector - the mining industry, the secondary sector - the manufacturing industry, and the tertiary sector - services (Parkhomenko et al., 2008). In the $60 \mathrm{~s}, \mathrm{~W}$. Isard, from the standpoint of the resource approach, investigated the mechanisms of migration phenomena, the processes of formation of metropolitan areas (Isard., 1960).

Quite a lot of publications by contemporary Russian authors are devoted to the issues of the formation of urban settlements, which have received the name "urban studies". The development of methods for assessing the gross urban product, as an integral indicator of the realization of the socio-economic potential of an urban area, are devoted to the publications of T.V. Uskova, Chekavinskaya, A.N., \& Lukin, E.V. (Uskova, Chekavinskaya, \& Lukin, 2013). The problems of modernizing a single-industry city and methodological approaches to the management of its construction complex are studied by M.A. Lunyakov, P.G. \& Grabovy (Lunyakov \& \& Grabovy, 2017). Scientific research by A.I. Treivish is devoted to the mechanisms of development of urban settlements from the standpoint of the institutional and reproductive approach; he believes that "the science of development, as part of the ideology of developmentalism, would be logical to call developmentology" (Treivish, 2009). The studies of N. Shipilova et al. (Shipilova, et al., 2017) are devoted to the modern problems of the functioning of the territories of resort cities, their innovative development.

The topic of regulation of the development of large cities, their relationship with small settlements remains debatable in the scientific community. Some authors consider the emergence and growth of megalopolises (cities with a million population) to be a normal natural phenomenon, while others are in favor of measures to limit their growth; the third group of 
authors believes that cities should harmoniously combine and closely interact with rural areas. (Druzhinin, \& Videnskaya, 2007).

The publications note the binary managerial quality of a modern city: on the one hand, the city is an object of management, on the other, it regulates its own life and the surrounding area of rural settlements. (Zotova, 2007). This last quality requires, in our opinion, additional comprehension and development of planning and regulation tools (Moiseev, 2013). A similar position is defended by a group of authors who interpret modern cities "as poles of economic life, structuring the surrounding space" (Parkhomenko et al, 2008). Recently, in publications on urban studies, there has been a reproductive emphasis in the assessment of urban settlements, their complex spatial-systemic content. At the same time, in terms of the prospects for the development of urban areas, the following approaches are very clearly observed: 1) city-society; 2) city-market; 3) citycorporation. In our view, each of these slices of urban life characterizes a quite tangible qualitative side of a modern city and should be evaluated in synergistic combination with the rest; the problem lies in maintaining the optimal proportions of such a combination. All this taken together indicates the vastness of the problem of managing the development of urban areas, its relevance.

\section{Materials and Methods}

The information basis for this study was the fundamental work in the field of spatial development, the formation of regional agglomerations and urban areas A.I. Treivish (Treivish, 2009), V.N. Ovchinnikov (Ovchinnikov \& Kolesnikov, 2008), monographs and articles of Russian and foreign authors, reporting data of state statistics bodies, information materials of regional administrations and municipalities, information from organizations, as well as observations of the authors of the article.

The theoretical and methodological basis of the research was the theory of systems, the theory of organizations, the principles of institutionalreproductive and systemic-synergetic approaches. Methods of functional-cost, case study and SWOT analysis, comparisons and generalizations were chosen in the role of the main ones. Conceptual constructions are formed on the basis of the analysis of the identified processes and conditions in modern urban planning practice, making forecasts for the development of the situation.

\section{Results and Discussion}

In the vast territory of Russia, we are witnessing the process of forming a new map of spatial development, pedalized by the interests of resource conservation, which is characterized by the accelerated growth of large cities, accompanied by less rapid development and even depression of small towns and villages in terms of population. The process of the formation of radially dispersed micro-industrial zones around large cities in their peripheral parts, which gradually merge into peripheral industrial and logistics rings, is quite noticeable. On the one hand, this helps to optimize passenger flows in the morning and evening hours (make it circular), on the other hand, it narrows the recreational zones of urban areas (recreation retreats to more distant boundaries).

Statistics show that the process of urbanization of Russian territories is only intensifying (Table 1).

Table 1.

Indicators of the urbanization process in the Russian Federation in 1989-2018 (Russian Statistical Yearbook. 2018)

\begin{tabular}{|c|c|c|c|c|c|c|c|}
\hline Indicators & 1989 & 2002 & 2010 & 2015 & 2016 & 2017 & 2018 \\
\hline Number of cities & 1037 & 1098 & 1100 & 1114 & 1112 & 1112 & 1113 \\
\hline $\begin{array}{l}\text { inhabitants in them, } \\
\text { thousand people } \\
\text { including those with a }\end{array}$ & 94450 & 95916 & 97527 & 100842 & 101651 & 102044 & 102387 \\
\hline $\begin{array}{l}\text { population of 500-999.9 } \\
\text { thousand people }\end{array}$ & 22 & 20 & 25 & 21 & 21 & 22 & 22 \\
\hline $\begin{array}{l}\text { inhabitants in them, } \\
\text { thousand people } \\
\text { cities with a population }\end{array}$ & 14040 & 12403 & 12755 & 12853 & 12931 & 13516 & 13576 \\
\hline $\begin{array}{l}\text { of } 1 \text { million or more } \\
\text { inhabitants in them, } \\
\text { thousand people }\end{array}$ & 12 & 13 & 12 & 15 & 15 & 15 & 15 \\
\hline
\end{tabular}




\begin{tabular}{|c|c|c|c|c|c|c|c|}
\hline $\begin{array}{l}\text { Urban settlements } \\
\text { inhabitants in them, } \\
\text { thousand people } \\
\text { cities with a population } \\
\text { of } 1 \text { million or more }\end{array}$ & 1037 & 1098 & 1100 & 1114 & 1112 & 1112 & 1113 \\
\hline $\begin{array}{l}\text { inhabitants in them, } \\
\text { thousand people }\end{array}$ & 2193 & 1842 & 1286 & 1192 & 1190 & 1192 & 1195 \\
\hline $\begin{array}{l}\text { Urban settlements } \\
\text { inhabitants in them, } \\
\text { thousand people }\end{array}$ & 13509 & 10513 & 7787 & 7259 & 7188 & 7171 & 7134 \\
\hline
\end{tabular}

(Krasnodar was included in the number of cities with a population of 1 million in 2019)

The data in Table 1 indicate some contradictions in the process of urbanization in the last third of the century: on the one hand, cities with a population of several hundred thousand are expanding, especially those exceeding 0.5 million inhabitants, on the other hand, urban-type settlements are significantly reduced. This fact is a reflection of the clearly expressed stagnation in the last three decades of monocities and monosettlements, those settlements that have formed on the basis of large industrial enterprises. In connection with the termination of the activities of such enterprises, the need for workers (and residents) has been lost. Extinct industrial enterprises in large cities were gradually replaced by construction projects, logistics, trade and other structures; this ensured a positive dynamics in the size of their population. The million-plus cities have entered the synergistic quality of selfsufficiency, which provides them with the effect of resource availability in production and consumption, employment and development, a synergistic effect of growth.

All of the above indicates the need for new approaches to the development and distribution of productive forces, planning of urban areas, solving problems of energy and resource supply of territories. Global processes are also pushing for this. If at the beginning of the last century only $4 \%$ of the population lived in the cities of the world, then by 2020 the share of the urban population was about $80 \%$. 3/4 of the population lives in Russian cities; statistics of recent decades indicate an annual growth of the urban population by $0.5-1.5 \%$.

The experience of the largest cities (Mexico City, Sao Paulo, Tokyo, New York, London, Delhi, Moscow) shows that there are practically no obstacles to their growth. This is due to the fact that in such cities the main issues of employment, consumer services are more efficiently resolved, comfort is higher, business is functioning more confidently; at the same time, as noted above, another set of problems is growing (overcoming crowding, providing recreation, transport regulation, etc.).
The growth of the city to the scale of a "millionplus city" translates it into a new organizational and economic quality, which is characterized by the presence of the following: several water intakes with appropriate treatment facilities and main distribution networks of large diameter; storm sewers capable of diverting storm drains from a large area in real time; several sewage treatment plants with appropriate collectors (including through-flow collectors with a diameter of $2 \mathrm{~m}$ ); detours in the peripheral part of the city for intercity traffic flows; several intracity highways with a set of overpasses to interchange intersecting traffic flows at different levels; high-speed passenger transport in the main directions of passenger traffic (metro, monorail, high-speed tram, etc.); several cultural centers corresponding to the largest ethnic groups of the urban population (religious, arts, education, ethno-cultural, children's creativity, etc.); strategic forms of interaction between government and business.

The growth of large cities to the scale of megalopolises has exhausted the resources for the development of a monocentric scheme for the location of industrial and socio-cultural facilities, the functioning of the urban economy, and brought their infrastructure to a dead end. The attempts made in such cities to damp passenger flows by creating production facilities in the peripheral zones to some extent solve the problem of transport provision of the urban economy and still require new initiatives and schemes (combining radial and circular traffic flows).

Until the last third of the twentieth century, the solution to the transport problem of the growing territories of cities was the car; however, later on, it not only facilitated passenger transportation, but also became the main source of life inconveniences for city dwellers (traffic, parking, gas pollution) (Sekisov, Ivanov \& Begiashvili, 2021). Observations show that with a monocentric layout scheme, urban highways of megalopolises are not able to provide timely evening and morning radial passenger traffic. 
One of the options for mitigating this problem may be to restrict the movement of private cars in the central part, while simultaneously creating intercepting parking lots and improving the public transport system, as has been done in Moscow in recent years. In some cities, special lanes are allocated for public transport, which speeds up passenger flows, but at the same time increases traffic for other transport, not only personal, but also freight, and this gives rise to other urban problems (supplying the retail network, the functioning of utilities, manufacturing enterprises, etc.).

Russia ranks second in the world after Brazil in the number of cities with a million inhabitants; moreover, in 3 cities (Saratov, Tyumen, Togliatti) the population is approaching 800 thousand, and in 7 cities (Izhevsk, Barnaul, Ulyanovsk, Irkutsk, Khabarovsk, Yaroslavl, Vladivostok) exceeded 600 thousand and is growing at an increased rate. This testifies to the new qualitative content of the urbanization process in modern Russia. In such a situation, in order to systematize knowledge in the development of socio-production systems in large cities, we believe it expedient to classify cities as the object of research as megacities, which in terms of population have approached the milestone of one million people. This will expand the field of research on the synergistic quality of urban mega-systems, and will allow the formation of an updated resource management toolkit for such mega-formations from the perspective of rational environmental management (so far, developments in this area are very rare). This is due to the fact that approaching the milestone of a million inhabitants, the city goes into a state of resource self-sufficiency: it is able to independently resolve issues of urban planning, education, medicine, ensuring the employment of the population, training, intellectualization of life. Such cities have a growing interest in international communication, solving environmental problems, they are actively involved in political, economic, cultural and educational processes. An analysis of demographic processes in Russian megalopolises indicates a fairly high and fairly stable rate of population growth $-0.5-1 \%$ per year (Table 2 ). This indicates the formation in Russia of a settlement structure characterized by elements of a new reproductive quality, which actualizes the need for updating state, municipal and even corporate management.

Table 2.

Dynamics of the formation of the population of megalopolises in Russia in 2017-2020 (partially calculated by the authors)

\begin{tabular}{llllll}
\hline & & Population as of & \multicolumn{2}{l}{$\begin{array}{l}\text { Population growth rate, } \\
\text { in \% }\end{array}$} \\
\cline { 4 - 6 } & Megapolis & 01.01 .2020 & $2018 / 2017$ & $2019 / 2018$ & $2020 / 2019$ \\
& & 16678074 & 1,02 & 0,87 & 0,49 \\
1 & Moscow & 5398064 & 1,33 & 0,60 & 0,26 \\
3 & St. Petersburg & 1625631 & 0,62 & 0,32 & 0,47 \\
3 & Novosibirsk & 1493749 & 0,92 & 0,97 & 0,72 \\
4 & Ekaterinburg & 1257391 & 0,94 & 0,68 & 0,43 \\
5 & Kazan & 1252236 & $-0,21$ & $-0,44$ & $-0,10$ \\
6 & Nizhny Novgorod & 1196680 & 0,29 & $-0,14$ & $-0,34$ \\
7 & Chelyabinsk & 1156659 & $-0,54$ & $-0,58$ & 0,00 \\
8 & Samara & 1164815 & $-0,54$ & $-0,62$ & $-0,88$ \\
9 & Omsk & 1133307 & 0,44 & 0,26 & 0,41 \\
10 & Rostov-on-Don & 1128787 & 0,45 & 0,33 & 0,41 \\
11 & Ufa & 1095286 & 0,73 & 0,41 & $-0,14$ \\
12 & Krasnoyarsk & 1058261 & 0,75 & 0,63 & 0,39 \\
13 & Voronezh & 1055397 & 0,34 & 0,22 & 0,14 \\
14 & Permian & 1008998 & $-0,12$ & 0,00 & $-0,44$ \\
15 & Volgograd & 932629 & 1,0 & 1,12 & 1,58 \\
16 & Krasnodar & & & & \\
\hline
\end{tabular}

Historical experience shows that, individually, an effective solution to the problems of the development of megalopolises can be the formation near large factories - small (with a population of 20-50 thousand people) satellite cities, combining work and home. From the standpoint of resource conservation, we see a promising polycentric scheme for organizing the urban area of large cities. This is consistent with the basic premise of the concept of new urbanism, according to which the population should work, live and rest in one place, with 


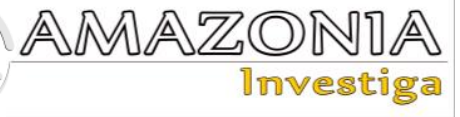

minimal displacement. Symptoms of the clustering of Russian industry that have emerged recently create favorable preconditions for the dispersal of enterprises and workshops across the territories adjacent to residential areas. This makes it possible to radically change the schemes of traffic flows, to close them within suburban economic clusters in the form of localized polycenters with autonomous administrative, economic, cultural, educational, educational, health-improving, recreational nuclei and objects of employment (enterprises, workshops, institutions, offices, offices, etc. etc.). With this construction of the general plan of the city, it becomes expedient to place resort and recreational zones on the borders of the polycenters, which will carry out their functions simultaneously for both sides. In this case, the polycenters can be connected by high-speed train routes, as well as high-speed buses. According to rough estimates, for the transport of 50 thousand people per hour in private cars, a lane width of 175 meters is required, on buses - 35 meters, and in a high-speed overhead train - 9 meters. In the latter case, depending on the specific situation, it can be a high-speed tram, a monorail car.

From the standpoint of the resource sustainability of territorial development, such a polycentric model of a city can be considered successful, in which about half of the working-age population of a polycentric microdistrict is employed within the boundaries of the zone of residence. It is advisable to develop options for a polycentric city model, taking into account the labor and other preferences of different population groups, as well as the interests of business, using methods of economic and mathematical modeling for poorly structured socio-economic systems using SWOT analysis methods (to assess the strength, weaknesses, opportunities and threats of each option). With the development of technology, the improvement of communications, the city is forced to rebuild; the polycentric model has a resource of increased flexibility for such restructuring.

The world practice of the formation of megalopolises indicates that such socioeconomic agglomerations have no boundaries of growth. A person is forced to live where there is work, and wants to live where such work can be chosen, as well as where life is more comfortable and more fun. This pattern is realized in the modern migration practice of the world and Russia. The emergence of a competitive market economy system in the Russian Federation has significantly changed the motivation for the spatial development of large cities, especially those that are deeply rooted in market mechanisms for motivating activities.

In recent years, along with the institutional mechanism of urban self-organization, a threelevel system of external influence on the development of the city and its spatial organization has actually been built (normatively and organizationally). First of all, this is the regional level of government, which has significant economic and other interests in the capital of the region. Regional authorities influence the city's space, its restructuring through real estate owned by a constituent entity of the Russian Federation, inter-budget transfers, investments from the regional budget, as well as various regulations (Mikheev et al., 2019). Federal authorities and administrations influence the functioning of the regional capital through investments that are commensurate in volume and often exceed investments from the regional budget. The third factor determining the development of a millionaire city is big business, whose positions have been significantly increasing in the last decade (this is very noticeable in the example of Krasnodar, Rostovon-Don, the regional centers of the Volga region - Volgograd, Nizhny Novgorod, Samara, Saratov). The market mechanisms of the Russian economy began to objectively "work" to increase the efficiency of using urban areas (Druzhinin, 2008). In the construction sector, such a resource-saving factor in the development of large cities manifested itself in the fact that small vacant lots or sparsely populated areas ("spots") with dilapidated buildings in the historical part of cities were the first to be reconstructed and built up. As the demand for apartments grew, developer investors began to show interest in the "densification" of multi-storey buildings in "dormitory" areas. In parallel with this, changes are taking place in the placement of communications. For example, in the city of Krasnodar, the issue of the removal of railways outside the city limits, the construction of elevated transport arteries, and the inclusion of the Kuban River flowing along the city into the transport system is under concrete consideration.

The spatial expansion of millionaire cities is largely facilitated not only by the real estate market, but also by the removal of restrictions on individual housing construction, including in the territories of horticultural associations. All this gave a significant impetus to the development of the zone of "internal suburbanization", and favored the positive dynamics of growth in the volume of housing commissioned. The market for contracting construction activities, the market 
for building materials, has developed in the corresponding order, which together provides integral time savings in construction activities.

\section{Conclusion}

The development and scaling of urban settlements in modern Russia was facilitated by such factors as maximizing the efficiency of resource use, saving time, greening environmental management, the desire of people for cultural communication and receiving social benefits.

The approach to the analysis and modeling of the urban economy from the standpoint of its consideration as a "quasi-corporation" presupposes the formation of a fairly holistic reproductive system based on the efficient use of the social and production resources of the territory. This translates the planning of the city's development into a business-process technology, a set of measures for pre-planned studies of socio-economic processes in the territory, calculations of the set performance indicators for the economy as a whole or for its individual subsystems for the future in terms of volumes, timing, performers, sources of resources, etc. In this case, each subsystem should be considered as a reproductive integrity that has specific causal parameters at the input and output, which, in fact, act as the main communication channels of this subsystem with other subsystems of the urban complex. The resulting plan of the urban socioeconomic system should be an integral set of plans of its subsystems. An important advantage of the business-process method of urban planning from the standpoint of resource conservation is its high compatibility with BIM technologies (Building Information Modeling), a predisposition to adjustments and, accordingly, updatability with the help of a computer over a long period of implementation of the strategic plan.

\section{Bibliographic references}

Druzhinin, A.G. (2008). Spatial development of a millionaire city: tendencies of the postSoviet period. Rostov on Don: SFedU Publishing House, 192, 75-77.

Druzhinin, A.G., \& Videnskaya, E.G. (2007). Determinants and features of the development of the largest cities as "growth poles" of the territorial-economic system of the South of Russia in the context of globalization. Izvestiya vuzov of the North Caucasus region. Social Sciences, No. 3, 50-58.
Isard, W. (1960). Methods of Regional Analisis: An Introduction to Regional Science. New York. (The translation of this book was published by the Progress Publishing House in 1966).

Lunyakov, M.A., \& Grabovy, P.G. (2017). Genesis and evolution of a single-industry city and the main directions of its modernization (electronic resource): monograph. Publishing house MICI Moscow State University of Civil Engineering, 209.

Mikheev, G. V., Sekisov, A. N., Gura, D. A., Abazyan, A. G, \& Kuznetsova, O. A. (2019) Economic and marketing adaptation of business processes in the modern russian real estate market / Revista Inclusiones, 6(2), 119-124 (Available at: http://www.archivosrevistainclusiones.com/ gallery/9\%20vol\%206\%20num\%202\%2020 19abriljunioasiaeuropaasia19incl.pdf

Moiseev, Yu.M. (2013). The capacity of the system of urban planning in conditions of uncertainty. Architecture and urban planning $\begin{array}{llll}\text { of } & \text { Russia, }\end{array}$ https://www.elibrary.ru/item.asp?id=189171 00 .

Ovchinnikov, V.N., \& Kolesnikov, Yu.S. (2008). Silhouettes of regional economic policy in the South of Russia. Rostov on Don: SFedU Publishing House, 176.

Parkhomenko, V.A., Tutarishev, B.Z., Tekhteneva, Z.I., \& Apriamashvili, M.G., (2008). The basics of territorial and spatial development of cities. City economy and the basics of spatial and economic development of urban areas. KubGTU. Krasnodar, 433, 151

https://www.elibrary.ru/item.asp?id=262132 57.

Russian Statistical Yearbook. (2018). Statistical collection. Moscow: Rosstat. R76., 686.

Sekisov, A., Ivanov L., \& Begiashvili, A. (2021). Improving the methodology of organizing the parking process in large cities of the world / IOP Conference Series: Materials Science and Engineering 1083 012072, Russian Federation (Available at: https://iopscience.iop.org/article/10.1088/17 57-899X/1083/1/012072/pdf doi: 10.1088/1757-899X/1083/1/012072

Shipilova, N.A, Savenko, A.A, Shikhovtsov, A.A, Sekisov, A.N., Popov, R.A., \& Mikheev, G.V. (2017). Organizational and technological aspect of innovation development of resort-Tourist locations of the Russian black sea. International Journal of Applied Business and Economic Research, Serials Publications, India, 15(23), 173-183 
(Available

at: https://serialsjournals.com/abstract/37837_1 6_natalia.pdf

Treivish, A.I. (2009). City, region, country and world. Development of Russia through the eyes of a country expert. Moscow: New chronograph, 372.

Uskova, T.V., Chekavinskaya, A.N., \& Lukin, E.V. (2013). Economic development of a large city: state, problems, prospects. Vologda: ISERT RAN, 128.
Weber, A. (1926) Yuber den Standort der Industrie. 1909. The theory of industrial placement. L. M. Univ. of Chicago Press, Chicago.

Zotova, M.V. (2007). Transformation of large cities of Russia into centers of macroregional influence (dissertation of the candidate of geographical sciences). Institute of Geography of the Russian Academy of Sciences, 29, Moscow. https://www.elibrary.ru/item.asp?id=158635 51 